\title{
Hydrogeological characterization and assessment of groundwater quality in shallow aquifers in vicinity of Najafgarh drain of NCT Delhi
}

\author{
Shashank Shekhar and Aditya Sarkar \\ Department of Geology, University of Delhi, Delhi 110 00\%, India. \\ *Corresponding author. e-mail: shashankshekhar01@gmail.com
}

\begin{abstract}
Najafgarh drain is the biggest drain in Delhi and contributes about $60 \%$ of the total wastewater that gets discharged from Delhi into river Yamuna. The drain traverses a length of $51 \mathrm{~km}$ before joining river Yamuna, and is unlined for about $31 \mathrm{~km}$ along its initial stretch. In recent times, efforts have been made for limited withdrawal of groundwater from shallow aquifers in close vicinity of Najafgarh drain coupled with artificial recharge of groundwater. In this perspective, assessment of groundwater quality in shallow aquifers in vicinity of the Najafgarh drain of Delhi and hydrogeological characterization of adjacent areas were done. The groundwater quality was examined in perspective of Indian as well as World Health Organization's drinking water standards. The spatial variation in groundwater quality was studied. The linkages between trace element occurrence and hydrochemical facies variation were also established. The shallow groundwater along Najafgarh drain is contaminated in stretches and the area is not suitable for large-scale groundwater development for drinking water purposes.
\end{abstract}

\section{Introduction}

The National Capital Territory (NCT) of Delhi (figure 1) is one of the fast growing metropolitan cities in the world. It faces a massive problem of voluminous generation of wastewater. This wastewater is mainly contributed by numerous drains of NCT Delhi that have considerable impact on surface water and groundwater systems of the territory. The effect on surface water is visible from river Yamuna where upstream of Wazirabad, the colour of river water is bluish/greenish which changes to dark grey downstream of Wazirabad, from where the Najafgarh drain joins river Yamuna (figure 1). Henceforth, a series of 19 drains joins river Yamuna, making it a giant drain. The impact of this wastewater on the groundwater system is even more profound. There is considerable contamination of groundwater by industrial and domestic effluents mostly carried through various drains (Singh 1999).

The Najafgarh drain is the biggest drain in NCT Delhi, discharging 287.5 million litres per day (MLD) (0.2875 million $\mathrm{m}^{3} /$ day) wastewater into river Yamuna (NEERI 2002). The Najafgarh drain contributes about $60 \%$ of the total wastewater that gets discharged from Delhi into river Yamuna (Kumar et al. 2006).

The Najafgarh drain enters Delhi from Haryana from the south-west corner of Delhi. It traverses a length of $51 \mathrm{~km}$ before joining river Yamuna (INTACH 2003). In its initial stage through

Keywords. Delhi; Najafgarh drain; contamination; groundwater salinity; hydrochemical facies; correlation matrix. 


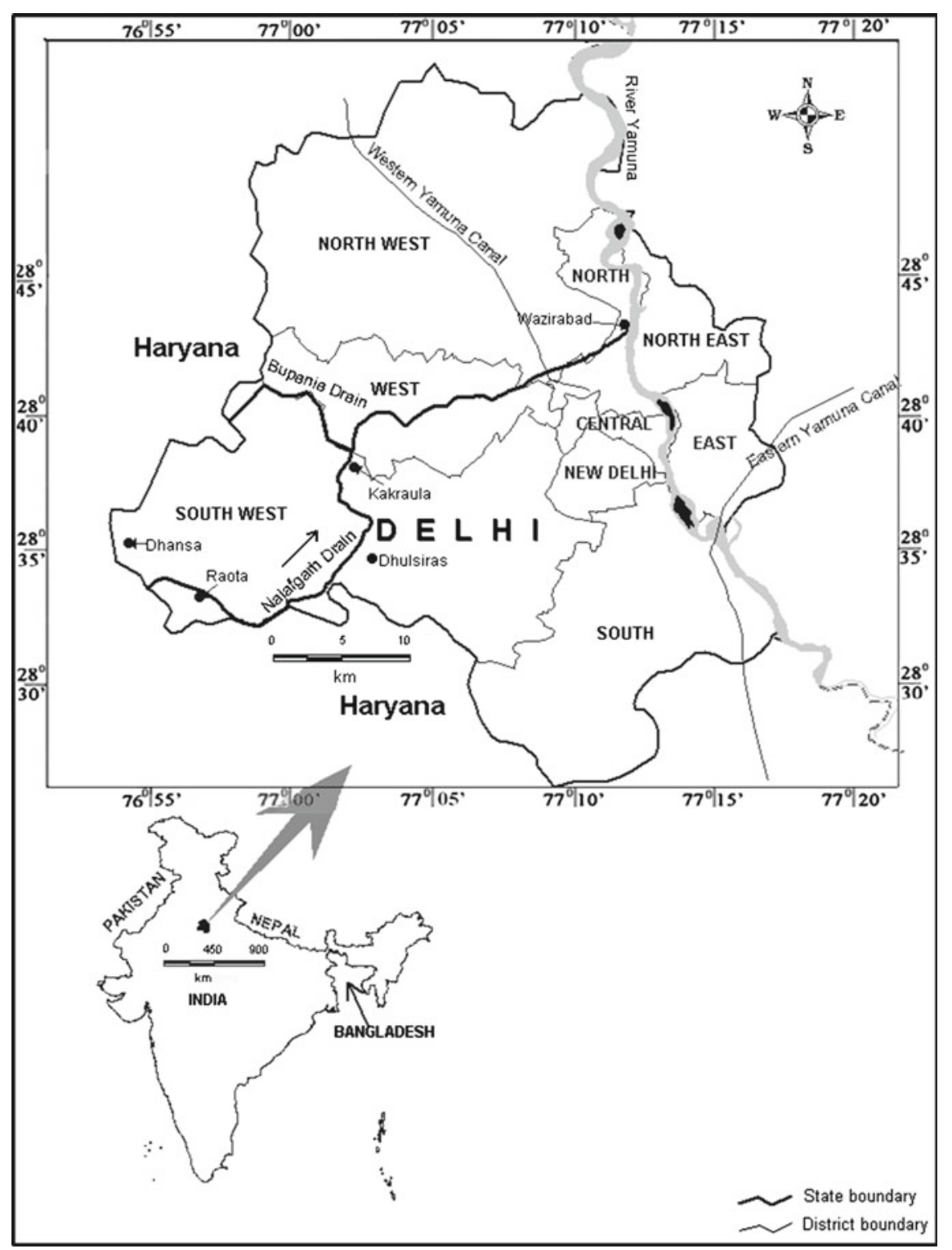

Figure 1. Delhi map with inset of India map, showing Najafgarh drain.

south-west district of NCT Delhi, the drain carries flood water, wastewater from Haryana and surface runoff from the adjoining catchment. Out of the $51-\mathrm{km}$ stretch of the drain, nearly $31-\mathrm{km}$ stretch of the drain passes through south-west district from near Dhansa to Kakraula (Jindal 1975) (figure 1). Thus, nearly $60 \%$ of the length of Najafgarh drain flows through south-west district of NCT Delhi and this entire stretch of the drain is unlined. Moreover, from Dhansa to Kakraula (figure 1), very few (may be 2-3 drains) subsidiary drains join this big drain and subsequently after Kakraula, nearly 38 big and small drains (figure 2) join Najafgarh drain (WAPCOS 1999). Thus, apparently (on visual observation) the quality of water flowing through the drain is better in the stretch from Dhansa to Kakraula (figure 1). There were proposals (Bajpai
2011; INTACH 2003; Shekhar 2006) suggesting limited groundwater withdrawal coupled with artificial recharge in this stretch of aquifer along the Najafgarh drain from Dhansa to Kakraula. However, it was also argued that unlined drains in recharge areas act as a source of pollution to groundwater (Kumar et al. 2006). In this perspective, it becomes important to assess groundwater quality in shallow aquifers in the vicinity of the Najafgarh drain.

\section{Hydrogeology of the study area}

The Najafgarh drain traverses through south-west, west, north-west and north districts of NCT Delhi 


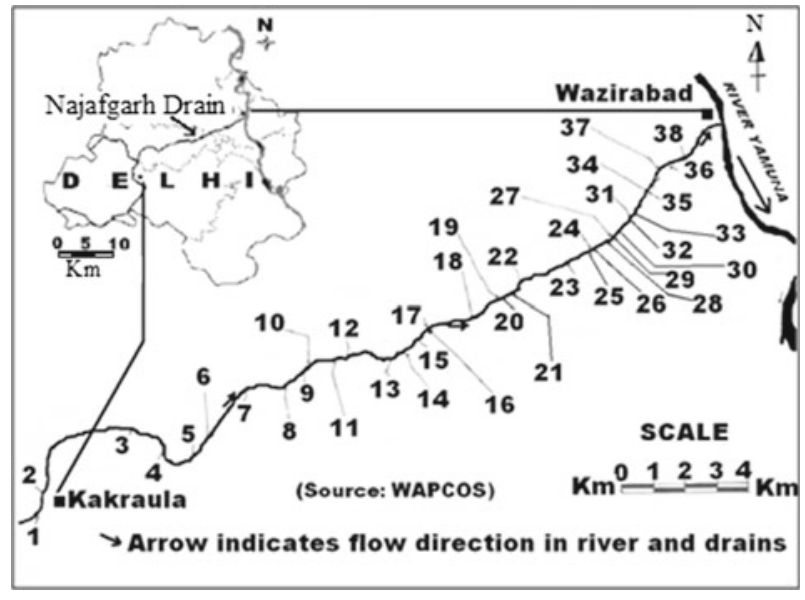

Figure 2. Map showing drains joining Najafgarh drain: 1. Palam drain, 2. Bupania drain, 3. Pankha road drain, 4. Vikaspuri drain, 5. Nilothi drain, 6. Sayed Nangloi drain, 7. Keshopur drain, 8. Subhash Nagar drain, 9. Khyala drain, 10. Jawalaheri drain, 11. Raghubir Nagar drain, 12. Madipur drain, 13. Ring Road drain, 14. Basai Darapur drain, 15. Ramesh Nagar drain, 16. Moti Nagar drain, 17. Punjabi Bagh drain, 18. Jaidev Park drain, 19. Shakur Basti drain, 20. Tulsi Nagar drain, 21. Anand Nagar drain, 22. Kanhiya Nagar drain, 23. Daryai drain, 24. Rana Pratap Bagh drain, 25. Shakti Nagar drain, 26. Shakti Nagar drain-2, 27. Gur Mandi drain, 28. G.T. Road drain, 29. Kamala Nagar drain, 30. Roop Nagar drain, 31. Vijay Nagar drain, 32. Hansraj drain, 33. Patel Chest drain, 34. Mall road drain, 35. Mall road drain-2, 36. Timarpur drain, 37. Power house drain, 38. Wazirabad drain.

(figure 1). The stretch of the drain through southwest and west districts is unlined, while stretch of the drain through north-west and west districts is lined. The borehole data and geophysical study reveals that subsurface formation along the area closely adjacent to drain has alternate fluvial and aeolian bands distributed sporadically. The alluvial deposits are Pleistocene in age with interbedded, lenticular and interfringing deposits of silty sand, clay and kankar. The proportion of finer sediment is higher. Goel (1990) in sieve analysis of borehole sediments from Dhulsiras (figure 1) revealed that in-depth range of 0 to $45 \mathrm{~m}$ below ground level (mbgl), nearly $60 \%$ is finer sand composition and rest is mixture of silt and clay. INTACH (2003) reported average rate of infiltration at the bed of the Najafgarh drain in south-west district of Delhi as $0.21 \mathrm{~mm} / \mathrm{h}$. They mention permeability of the subsurface formations below and adjacent to the Najafgarh drain in the stretch of the drain from Dhansa to Kakraula (figure 1) as ranging from 3 to $6 \mathrm{~m} /$ day to $28.11 \mathrm{~m} /$ day and transmissivity of the formation as ranging from $63.05 \mathrm{~m}^{2} /$ day to $927.7 \mathrm{~m}^{2} /$ day.

Throughout south-west district and major part of west district, the depth to bedrock below Najafgarh drain and its adjacent area is in the range of 200-300 mbgl (Shekhar 2004). As the drain in its later part takes a bend from $\mathrm{N}-\mathrm{S}$ orientation to nearly $\mathrm{E}-\mathrm{W}$ and flows eastward to join river Yamuna, it is gradually moving towards surface exposure of hard rocks (CGWB 2006) (figure 3). Thus, thickness of the non-indurated aquifers that are more prone to contamination decreases towards later part of the drain.

The Najafgarh drain and its tributaries show the effect of recharge from the water being carried by drain and it is evident in the form of greater depth to fresh/saline interface in groundwater (Shekhar et al. 2005). Shekhar et al. (2005, 2006) envisaged an elongated fresh groundwater lens along the Najafgarh drain in south-west district stretch of the drain. The salinity of groundwater increases as depth increases. The shallower groundwater all along Najafgarh drain and its close vicinity has lower salinity. The fresh groundwater aquifer thickness along Najafgarh drain is more in the unlined section of the drain. The surface water level along the drain from Dhansa to Kakraula (figure 1) is such that there is some depth of water in the drain throughout its length even when there is no flow. This situation helps in recharging groundwater in favourable conditions (when water table is below the water level in the drains). Bajpai (2011) established through remote sensing study that the Najafgarh drain and its tributaries in its initial stretch through south-west district of Delhi (figure 1) flows through a naturally defined valley setting. Thus, the hydrogeological equilibrium of the water in the drain and the adjacent aquifer in its initial stretch is similar to stream-aquifer interaction.

Shekhar et al. (2006) mentioned that in aquifers adjacent to the Najafgarh drain, there are isolated patches showing concentration of fluoride beyond permissible limit. Since groundwater in the fluoride-affected areas has higher salinity, it is possible that the high level of fluoride is due to localized effects of natural sources.

\subsection{Depth to water level in the study area}

A regional depth to water level map (figure 4) including areas much beyond close vicinity of the Najafgarh drain was prepared to gain an insight into regional and local variations in depth to water level of the area. The depth to water level in the areas closely adjacent to the drain varies in the range of 3 to $16 \mathrm{mbgl}$ (figure 4). The shallower depth to water level is noticed in initial part of the drain where it enters Delhi and in later part of the drain where it meets river Yamuna. The relatively deeper water levels are found in middle stretch of the drain. In areas to right in 


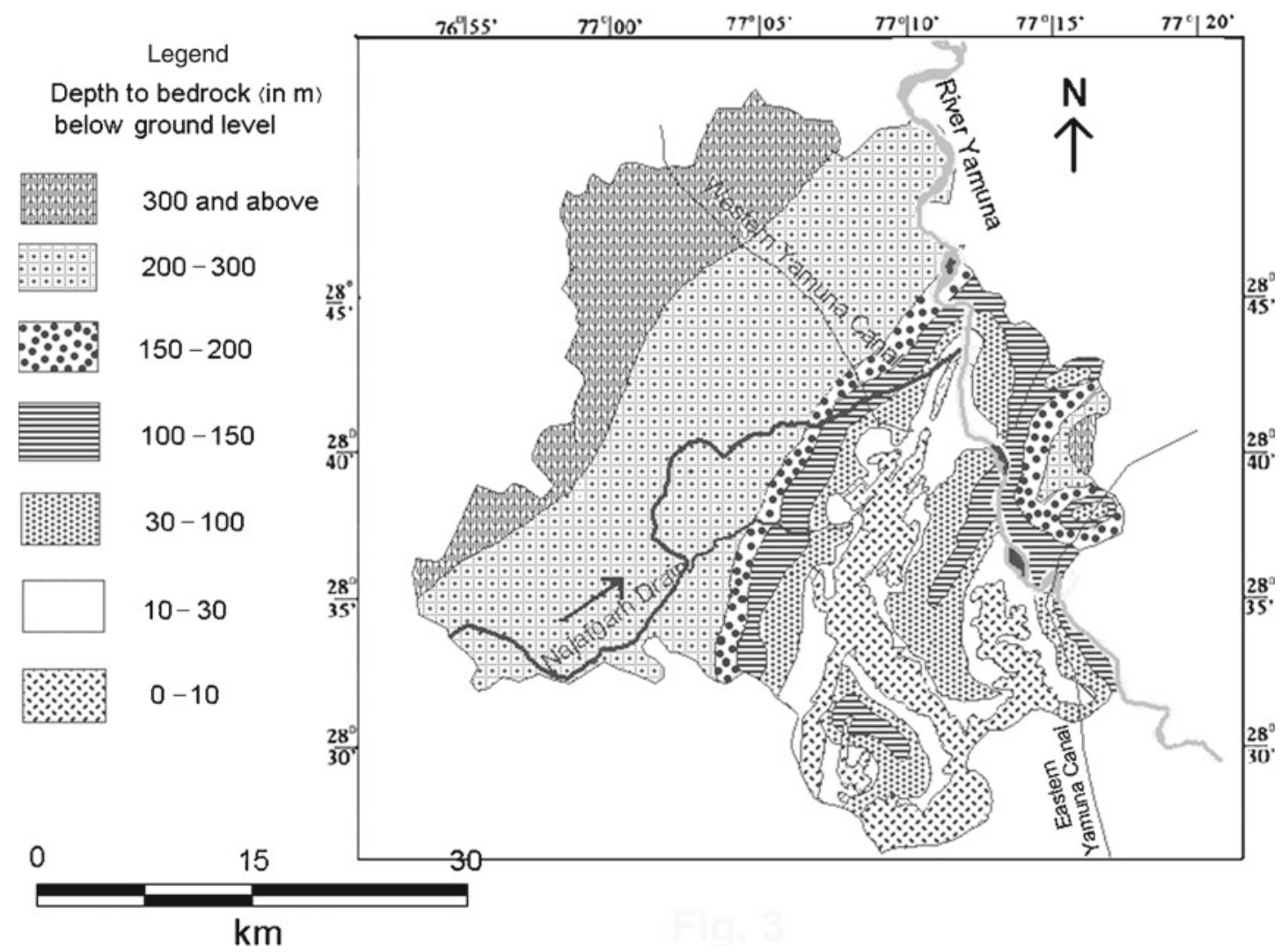

Figure 3. Depth to bedrock map in the study area.

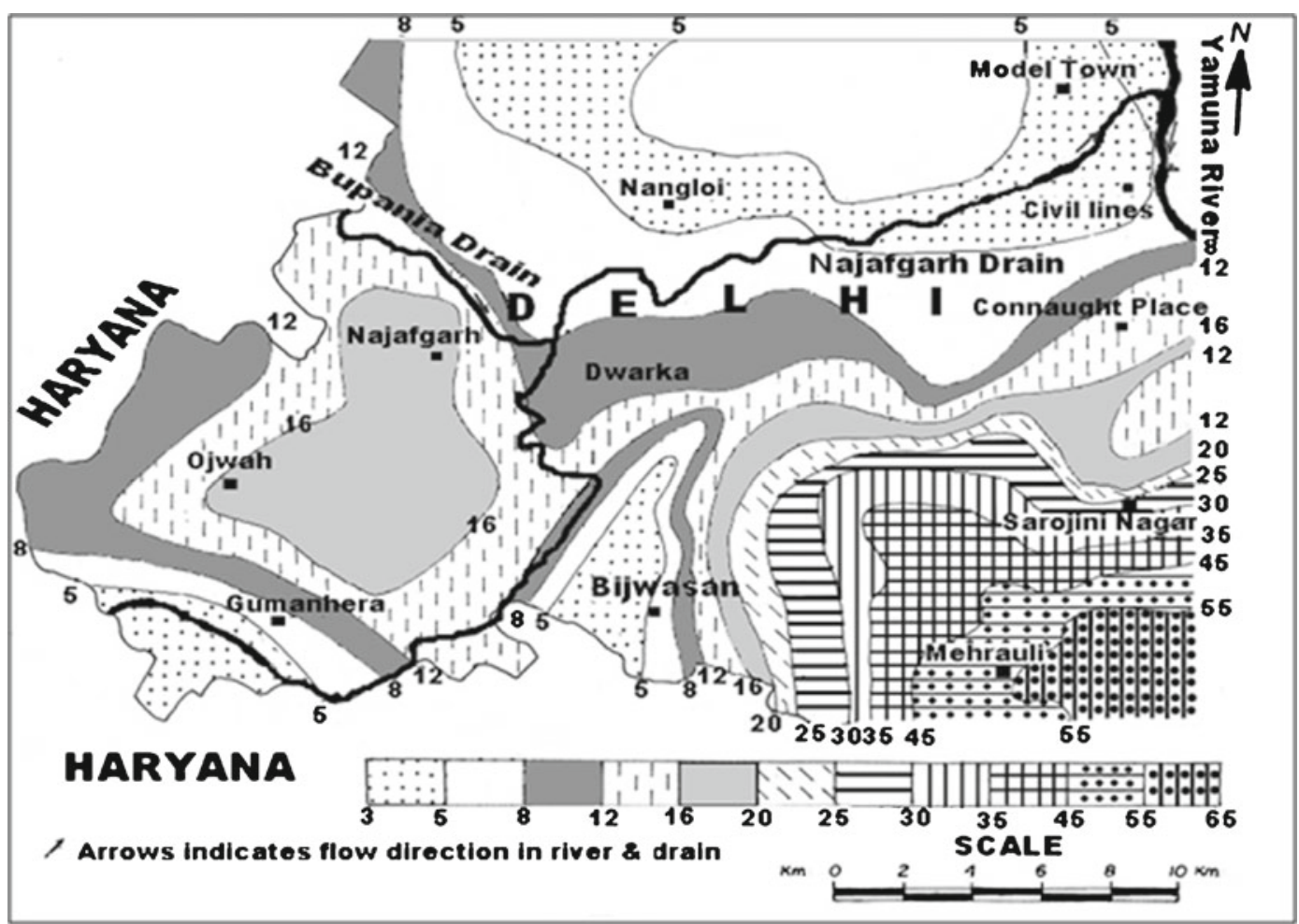

Figure 4. Depth to water level map in the study area. 
downstream of the drain, depth to water level increases as one moves in south-east direction and reaches a maximum of $65 \mathrm{mbgl}$, some kilometres ahead (these areas are adjacent to the hard rocks). Shekhar et al. (2009) also mentions about deeper depth to water level in the range of 40 $60 \mathrm{mgbl}$ in these areas of Delhi shown in figure 4 . In areas to left of the drain, relatively shallower depth to water level is found, reaching to maximum of $20 \mathrm{mbgl}$ in Najafgarh and Ojwah areas (figure 4). The groundwater in areas with relatively shallower depth to water level is more vulnerable to anthropogenic contamination.

\subsection{Water table elevation in the study area}

A regional water table elevation map (figure 5) including areas much beyond close vicinity of Najafgarh drain was prepared to gain an insight into regional and local variations in water table elevation of the area. The water table elevation in areas adjacent to Najafgarh drain is found in the range of 197 to $206 \mathrm{~m}$ above mean sea level (mamsl) (figure 5). The higher water table elevation is noticed in initial part of the drain where it enters Delhi and in later part of the drain (later half segment of the drain before it joins river Yamuna). The lower water table elevations are found in the $\mathrm{N}-\mathrm{S}$ stretch of the drain (figure 5). The regional water trough near Ojwah defined by 194 mamsl contour has a tremendous influence on groundwater flow to the extent that in first half stretch of the Najafgarh drain, groundwater flow from areas adjacent to the drain and others converge towards it. Thus, in this stretch of the drain on left-side areas, groundwater flow seems to be away from the drain, while on right side of the drain, groundwater flow is towards the drain (figure 5). In later half stretch of Najafgarh drain apparently on left side of the drain, groundwater flow is towards the drain. While in areas on right side in downstream of the drain, in some stretches, there seems to be not much of groundwater flow; and in some areas/stretches, groundwater seems to be flowing away from the drain (figure 5). In areas where groundwater flow is away from the drain, there is possibility that contaminants entering the groundwater system are transported to relatively greater distance by advection along with the groundwater flow direction. The above-mentioned hydrogeological characteristics of the area (depth to water level, water table elevation, aquifer parameters, aquifer material, infiltration rates, etc.) hint at dynamic interaction between the water flowing through the drain and groundwater, thereby affecting the quality of groundwater.

\section{Methodology for assessment of groundwater quality}

The approach to assessment of groundwater quality in shallow aquifers in the vicinity of Najafgarh drain of NCT Delhi involved groundwater sampling at evenly distributed locations all along the

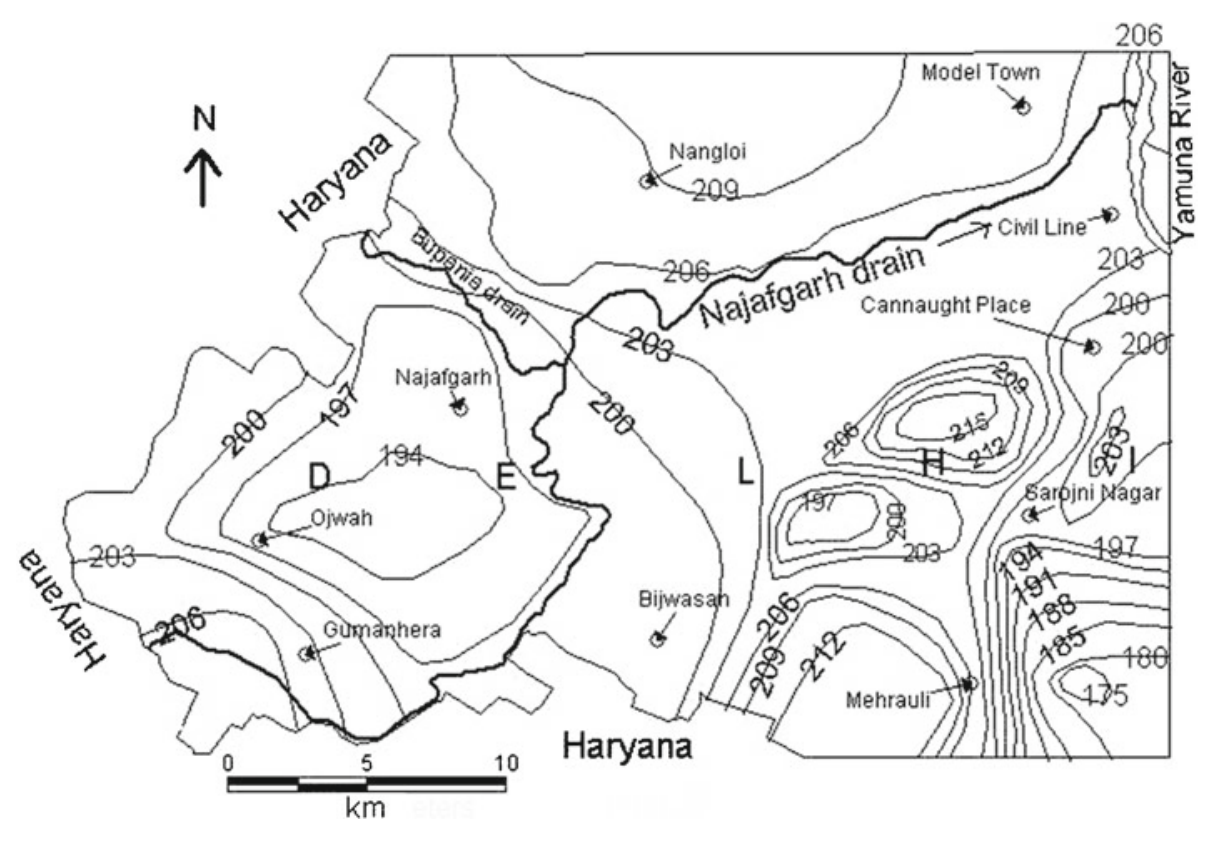

Figure 5. Water table elevation map of the study area. 
drain. The sampling was done mainly during premonsoon period in May from hand pumps in the areas adjacent to the drain.

Acid-treated samples were collected for trace element/heavy metal analysis and normal samples for major element analysis. The samples were analysed at Central Ground Water Board (CGWB) chemical laboratory at Chandigarh using atomic absorption spectroscopy (AAS), ion chromatography and volumetric titration techniques (Shekhar 2008). Sampling locations varied from sites located approximately at a distance of 3-600 $\mathrm{m}$ from the drain (figure 6). It was observed subsequently during analysis that the samples, which were relatively away from the drain, had lesser amount of anthropogenic contaminants. The variations in concentration of the chemical components were studied in the perspective of permissible limit of drinking water following Bureau of Indian Standards (BIS 1991) and World Health Organization standards (WHO 2011). The variation in chemical constituents in groundwater was also studied to observe the pattern of similarity/dissimilarity in various chemical constituents in space, and to account for the observed patterns. The study of hydrochemical facies of the groundwater was conducted with the help of Hill-Piper Trilinear plot. The Hill-Piper trilinear plot was prepared for 21 groundwater samples where all the necessary data for hydrochemical facies classification was present.
AquaChem software was used for creating multiple parameter plot (Hill-Piper trilinear plot) and correlation matrices (Sarkar 2011).

\section{Results}

In perspective of BIS standards for drinking water (1991), 88\% of the collected groundwater samples showed concentration of iron beyond permissible limit prescribed for drinking water of $1 \mathrm{mg} /$ litre (BIS 1991) and $23 \%$ of groundwater samples showed concentration of manganese beyond their prescribed permissible limit for drinking water of $0.3 \mathrm{mg} /$ litre (BIS 1991). It must be mentioned that WHO (2011) gives no specific guidelines for permissible limit of iron and manganese in drinking water. In about $42 \%$ of the samples, concentration of nitrate exceeded the permissible limit prescribed for drinking water of $45 \mathrm{mg} /$ litre (BIS 1991); while in perspective of WHO (2011) standards, about $35 \%$ samples had concentration of nitrate beyond the permissible limit prescribed for drinking water of $50 \mathrm{mg} /$ litre. Arsenic exceeded their prescribed permissible limit for drinking water of $0.01 \mathrm{mg} /$ litre (BIS 1991), (WHO 2011) in about 3\% of the samples. Cadmium exceeded their prescribed permissible limit for drinking water of $0.01 \mathrm{mg} /$ litre (BIS 1991) in about 3\% of the samples; while in

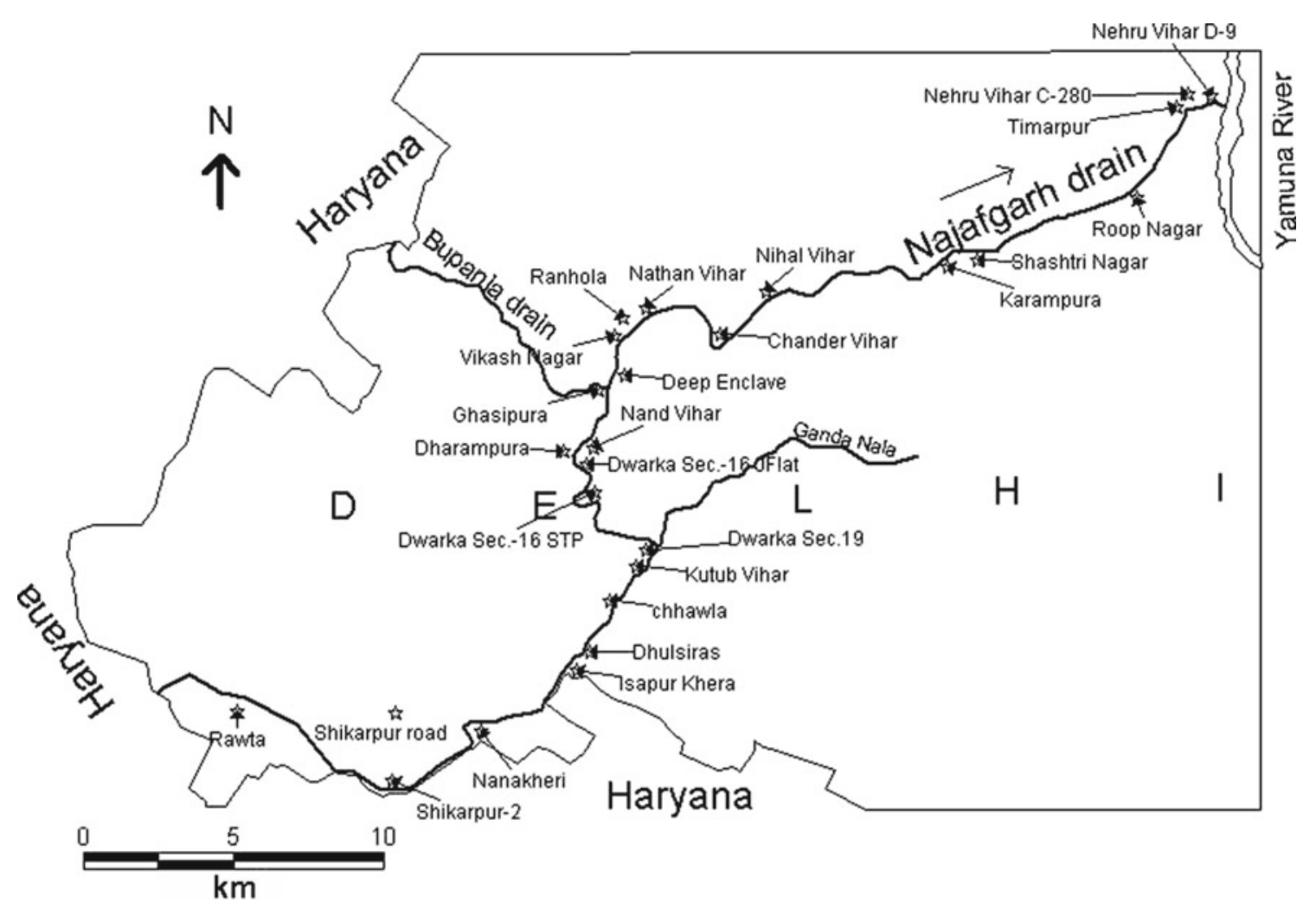

Figure 6. Map showing sampling locations of the study area. 


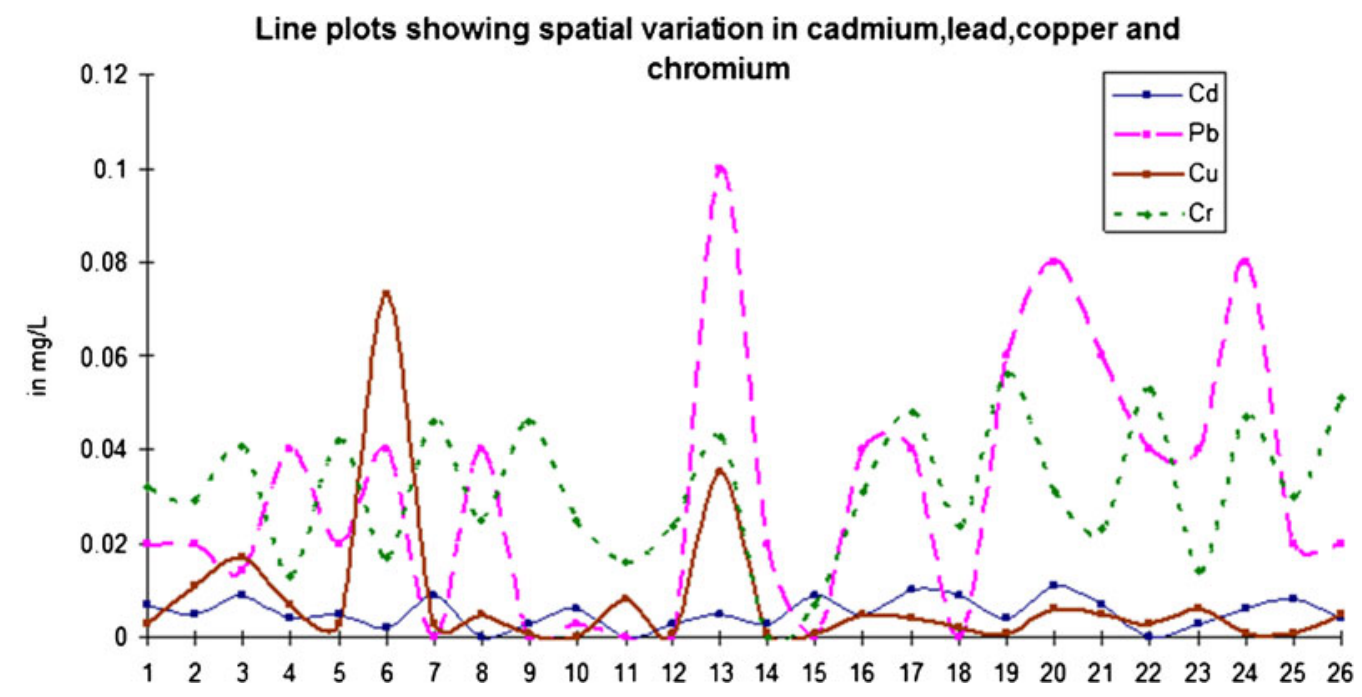

Figure 7. Line plots showing spatial variation in cadmium $(\mathrm{Cd})$, lead $(\mathrm{Pb})$, copper $(\mathrm{Cu})$ and chromium $(\mathrm{Cr})$ for 1 . Rawta, 2. Shikarpur road, 3. Shikarpur-2, 4. Nanakheri, 5. Isapur Khera, 6. Dhulsiras, 7. Chhawla, 8. Kutub Vihar, 9. Dwarka Sec. 19, 10. Dwarka Sec. 16 STP, 11. Dharampura, 12. Dwarka Sec. 16 J Flat, 13. Nand Vihar, 14. Ghasipura, 15. Deep Enclave, 16. Vikash Nagar, 17. Ranhola, 18. Nathan Vihar, 19. Chander Vihar, 20. Nihal Vihar, 21. Karampura, 22. Shashtri Nagar, 23. Roop Nagar, 24. Timarpur, 25. Nehru Vihar D-9, 26. Nehru Vihar C-280 groundwater sampling locations.

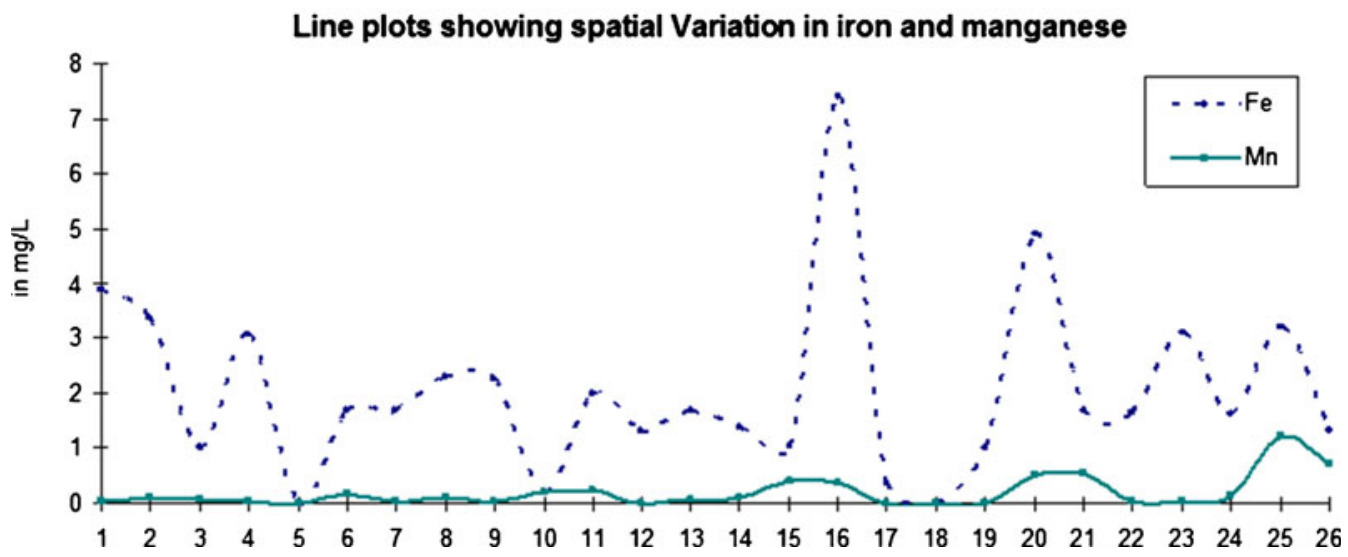

Figure 8. Line plots showing spatial variation in Iron (Fe) and Manganese (Mn) for 1. Rawta, 2. Shikarpur road, 3. Shikarpur2, 4. Nanakheri, 5. Isapur Khera, 6. Dhulsiras, 7. Chhawla, 8. Kutub Vihar, 9. Dwarka Sec. 19, 10. Dwarka Sec. 16 STP, 11. Dharampura, 12. Dwarka Sec. 16 J Flat, 13. Nand Vihar, 14. Ghasipura, 15. Deep Enclave, 16. Vikash Nagar, 17. Ranhola, 18. Nathan Vihar, 19. Chander Vihar, 20. Nihal Vihar, 21. Karampura, 22. Shashtri Nagar, 23. Roop Nagar, 24. Timarpur, 25. Nehru Vihar D-9, 26. Nehru Vihar C-280 groundwater sampling locations.

perspective of the WHO (2011) prescribed permissible limit for drinking water, it exceeded the limit of $0.003 \mathrm{mg} /$ litre in about $69 \%$ of the samples. As per WHO (2011) guidelines, chromium exceeded the prescribed permissible limit for drinking water of $0.05 \mathrm{mg} /$ litre in about $12 \%$ of the samples; while in perspective of BIS (1991) prescribed permissible limit for drinking water, all the samples were well within the prescribed permissible limit of $0.1 \mathrm{mg} /$ litre. In about $69 \%$ of the samples, lead exceeded the prescribed permissible limit for drinking water of $0.01 \mathrm{mg} /$ litre as per WHO (2011) guidelines; while in perspective of BIS (1991) standards for drinking water, about $19 \%$ samples had lead concentration in groundwater above the prescribed permissible limit of $0.05 \mathrm{mg} /$ litre. The groundwater quality database used in the study is attached as supplementary material with the paper (Appendix A).

The concentration of chemical constituents such as chromium, copper, lead and cadmium in groundwater when plotted with respect to the 
sampling location showed roughly cyclic behaviour (figure 7). Similar patterns were observed for concentration versus sampling location plots for iron and manganese (figure 8). The spatial variation in the above-mentioned chemical constituents in the groundwater samples was prominent. These cyclic patterns may be on account of numerous subsidiary drains joining Najafgarh drain, accelerating the anthropogenic enrichment in groundwater. However, such trends were not observed for other constituents such as arsenic, nickel, magnesium and fluoride due to their absence in samples or unavailable data from some locations.

These plots are useful in assessing spatial variation in concentration of different groundwater contaminants but they are not enough to relate the similarity/dissimilarity among chemical contaminants. Hence, a correlation coefficient matrix was prepared for 21 out of 26 sampling locations, which provided sufficient information for all analysed chemical constituents (table 1).

The high correlation coefficient value of electrical conductivity with chloride pointed to the fact that salinity could be mainly chloride controlled. The higher salinity in groundwater is attributed to longer retention time of groundwater and lack of flushing in general and in very shallow water level areas, repeated oxidation and evaporation may have led to salinity enrichment in groundwater.

The significant positive correlation coefficient value between nitrate and sodium, nitrate and potassium, nitrate and magnesium and nitrate and chloride established degradation in groundwater quality due to infiltration of the wastewater from Najafgarh drain. The inference is further authenticated by relatively high correlation coefficient value between chloride and sulphate. The significant positive correlation coefficient value between fluoride and bicarbonate coupled with high level of fluoride in a few locations (see Appendix A) suggests contamination of the groundwater at a few locations by excess use of fertilizers.

In most sampling locations, nickel was absent in the groundwater. However, in places where traces of nickel was found, it showed good correlation with Iron $(\mathrm{Fe})$, chromium $(\mathrm{Cr})$ and zinc $(\mathrm{Zn})$. It is possible that the trace heavy metals in groundwater were introduced as anthropogenic contamination from industrial wastes of metal processing industries present in the catchment of the Najafgarh drain system.

Moturi et al. (2004) established that solid wastes from the industrial belt of Delhi had high mean level of toxic metals and opined that these toxic metals are produced by small-scale metal processing industries. Banerjee (2003) analysed dust samples from some of the industrial areas

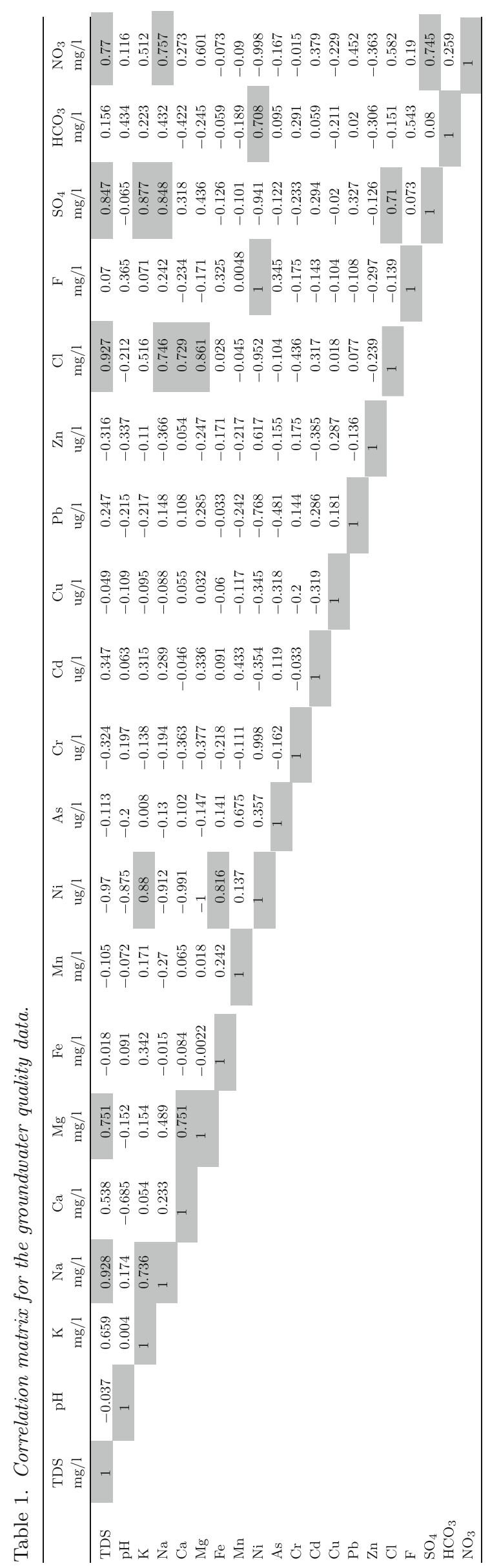


in Najafgarh drain catchment and concluded that these samples had high concentration of heavy metals such as chromium, copper and nickel which are linked to industrial sources.

Manganese showed significant positive correlation coefficient value with arsenic indicating a common source for both of them. In about $23 \%$ of the samples, manganese concentration in groundwater was beyond the prescribed limit for drinking water of $0.3 \mathrm{mg} /$ litre (BIS 1991). Since it has been established that high concentration of heavy metals is linked to industrial sources, it is possible that higher concentration of manganese in groundwater is also contributed by industrial wastes. It suggested that the geogenic inputs of manganese in groundwater system was further enhanced by anthropogenic sources. Since arsenic correlated well with manganese, its concentration in groundwater could be linked to anthropogenic sources. Lalwani et al. (2004) had a similar observation and opined that the arsenic contamination in groundwater of Delhi could be from the arsenic present in garbage of open landfill sites rich in chemicals. Dubey et al. (2012) confirmed anthropogenic source for arsenic contamination in groundwater of Delhi.

The correlation matrix could be an effective tool to understand the relationship among different major physiochemical parameters and trace elements, but hydrochemical facies could be further used to assess the nature and portability of groundwater. The Hill-Piper plot is one of the premier graphical plots for delineating hydrochemical facies. The Hill-Piper plot was prepared for the 21 samples, which provided sufficient information. The plot (figure 9) revealed that the major water facies types in the studied locations were $\mathrm{Na}-\mathrm{Mg}-\mathrm{Cl}-\mathrm{HCO}_{3}, \mathrm{Na}-\mathrm{Mg}-\mathrm{HCO}_{3}-\mathrm{Cl}, \mathrm{Na}-\mathrm{Cl}-\mathrm{HCO}_{3}$, $\mathrm{Na}-\mathrm{HCO}_{3}-\mathrm{Cl}, \mathrm{Na}-\mathrm{Mg}-\mathrm{Ca}-\mathrm{HCO}_{3}-\mathrm{Cl}, \mathrm{Na}-\mathrm{K}-\mathrm{Cl}-\mathrm{SO}_{4}$ and $\mathrm{Mg}-\mathrm{Na}-\mathrm{Ca}-\mathrm{Cl}-\mathrm{HCO}_{3}$ types (Sarkar 2011). It becomes clear from the trilinear plot (figure 9) that the dominant cations in the hydrochemical facies are prominently sodium with magnesium, while the anions vary mainly from chloride to the bicarbonate end of the plot. As mentioned earlier, the bicarbonate ions showed good correlation with nickel and sulphate ions showed good correlation with nitrate, while chloride ions do not show prominent correlation with any trace element and moderate correlation with nitrate. In this context, it can be inferred that originally the groundwater facies in the area was chloride type, the process of dilution by influx of drain water into groundwater system could have led to the changes in the groundwater facies originally from chloride type towards bicarbonate type. Thus, it can be said
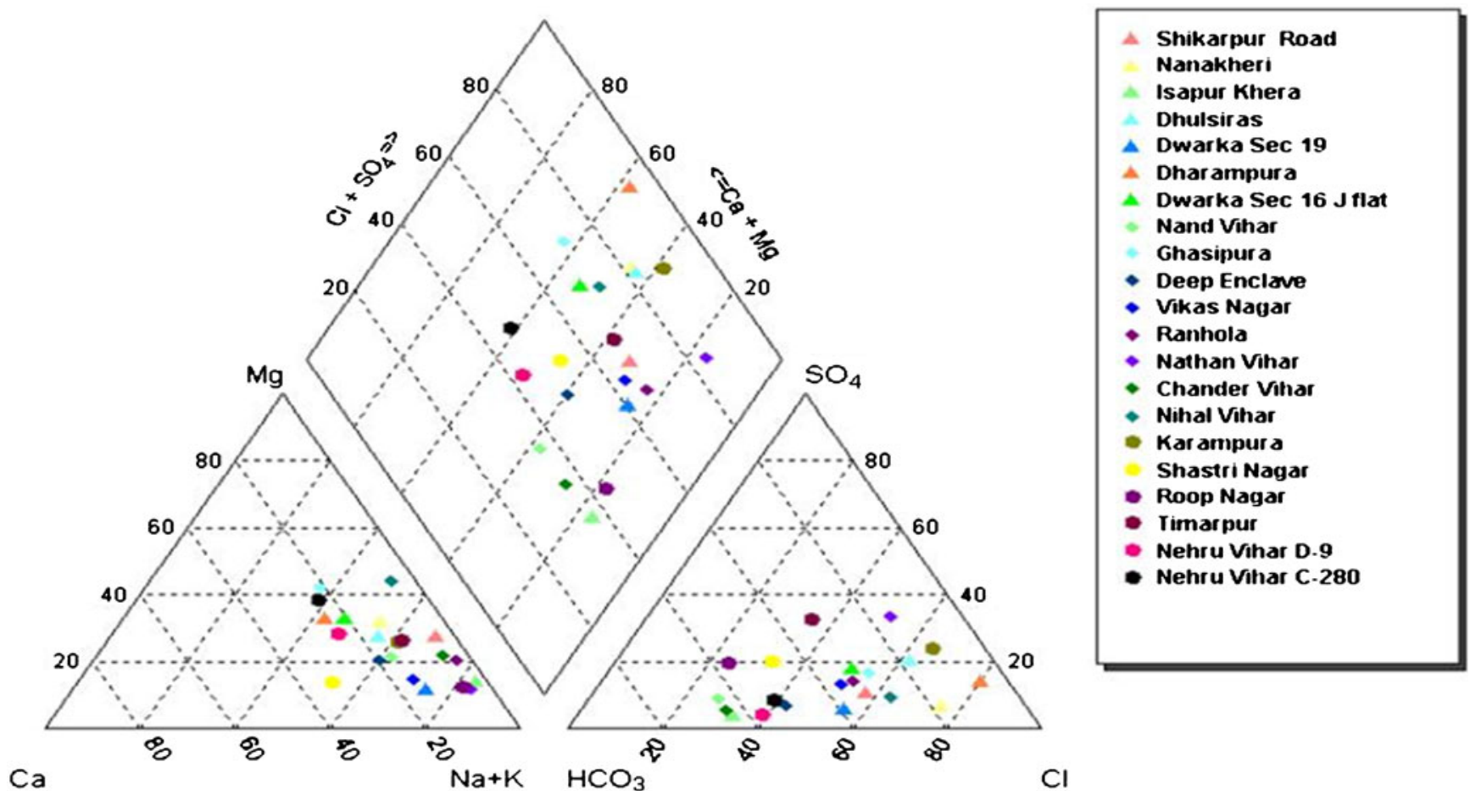

Figure 9. Hill-Piper plot for the groundwater quality data. 
that the anthropogenic contamination of groundwater system by the drain water and the trace element in the drain water simultaneously changed the groundwater facies.

\section{Discussion}

Hydrogeological characteristics of the catchment of the Najafgarh drain system and aquifer parameters of the formation along the Najafgarh drain establish vulnerability of groundwater to contamination by wastewater flowing through the drain. It has also been indicated by isotopic study (Datta et al. 1996) that there is seepage recharge from surface water courses in Delhi. In case of the Najafgarh drain, mixing of seepage recharge from the drain with water coming from adjacent highlands has been reported (Kumar et al. 2011).

The Najafgarh drain water was reported to contain considerable concentration of heavy metal contaminants such as iron, lead, manganese, copper and nickel (Sharma et al. 2004). Hence, it is quite possible that along with seepage recharge from the drain, the heavy metal contaminates the groundwater as well. However, a recent study by Lorenzen et al. (2011), based on bank filtration technique, proposed groundwater extraction from the aquifer near the drain for drinking purposes. The shallow aquifer in this area is contaminated in different stretches. Thus, any groundwater development for emergency requirement should be preceded by microlevel groundwater quality study. The groundwater pumping in such areas must be staggered in space and time to control saline water upconing (Rao et al. 2006, 2007).

A system simulation and numerical modelling study can suggest optimal pumping from the aquifer under different possible scenarios. The model can incorporate possibilities of contaminant transport from sampling locations where contaminants have been reported. It is also suggested that the sewage treatment level can be estimated so that the drain bank filtrated water into aquifer attains portable drinking water standards. This can be enforced on the concerned authorities undertaking sewage treatment projects along the drain.

\section{Conclusion}

The study gives a detailed insight into hydrogeology of the area adjacent to the Najafgarh drain and groundwater quality in shallow aquifers along the Najafgarh drain. It establishes contamination of groundwater system in vulnerable stretches by wastewater flowing through the drain. It has been established that originally the groundwater in the aquifers had evolved to chloride facies, where the total dissolved solutes in groundwater was contributed mainly by geogenic sources. The groundwater recharge to shallow aquifers along the drain caused dilution of the chloride facies water leading to re-evolution of the groundwater facies towards bicarbonate type. In this process, the groundwater quality was degraded by anthropogenic contaminants from wastewater flowing through the drain. Thus, recharge through drain water led to influx of trace element/heavy metals in groundwater. This establishes the fact that anthropogenic contamination of the groundwater simultaneously leads to changes in the hydrochemical facies of the groundwater. The influx of contaminants into groundwater system through network of subsidiary drains is also evident from the pattern of spatial variation in the concentration of the groundwater contaminants. Hence, the study on anthropogenic contamination of groundwater system should be coupled with hydrochemical facies analysis for comprehensive assessment of groundwater quality.

\section{Acknowledgements}

Author (AS) thanks the Council of Scientific and Industrial Research for financial grant through a junior research fellowship. It is duly acknowledged that the groundwater sampling was done by the first author when he was working as a Scientist at Central Ground Water Board and the samples were analysed at CGWB Laboratory, Chandigarh. The data for publication was taken from CGWB Report by Shekhar (2008). The authors are grateful to anonymous reviewers for their meticulous review of the manuscript, which helped in improving the manuscript.

\section{Appendix A}

Table showing the location of sampling stations and the concentration of different chemical parameters. Cd - Cadmium, Cr - Chromium, $\mathrm{Cu}$ - Copper, $\mathrm{Fe}$ - Iron, Mn - Manganese, $\mathrm{Ni}$ - Nickel, Pb - Lead, Zn - Zinc, As - Arsenic, EC - Electrical conductivity, Cl - Chloride, $\mathrm{SO}_{4}$ - Sulphate, $\mathrm{NO}_{3}$ - Nitrate, $\mathrm{F}$ - Fluoride, $\mathrm{Ca}$ - Calcium, Mg - Magnesium, Na - Sodium, $\mathrm{K}$ - Potassium, $\mathrm{HCO}_{3}$ - Bicarbonate, N.A. - Not analysed/data not available. 


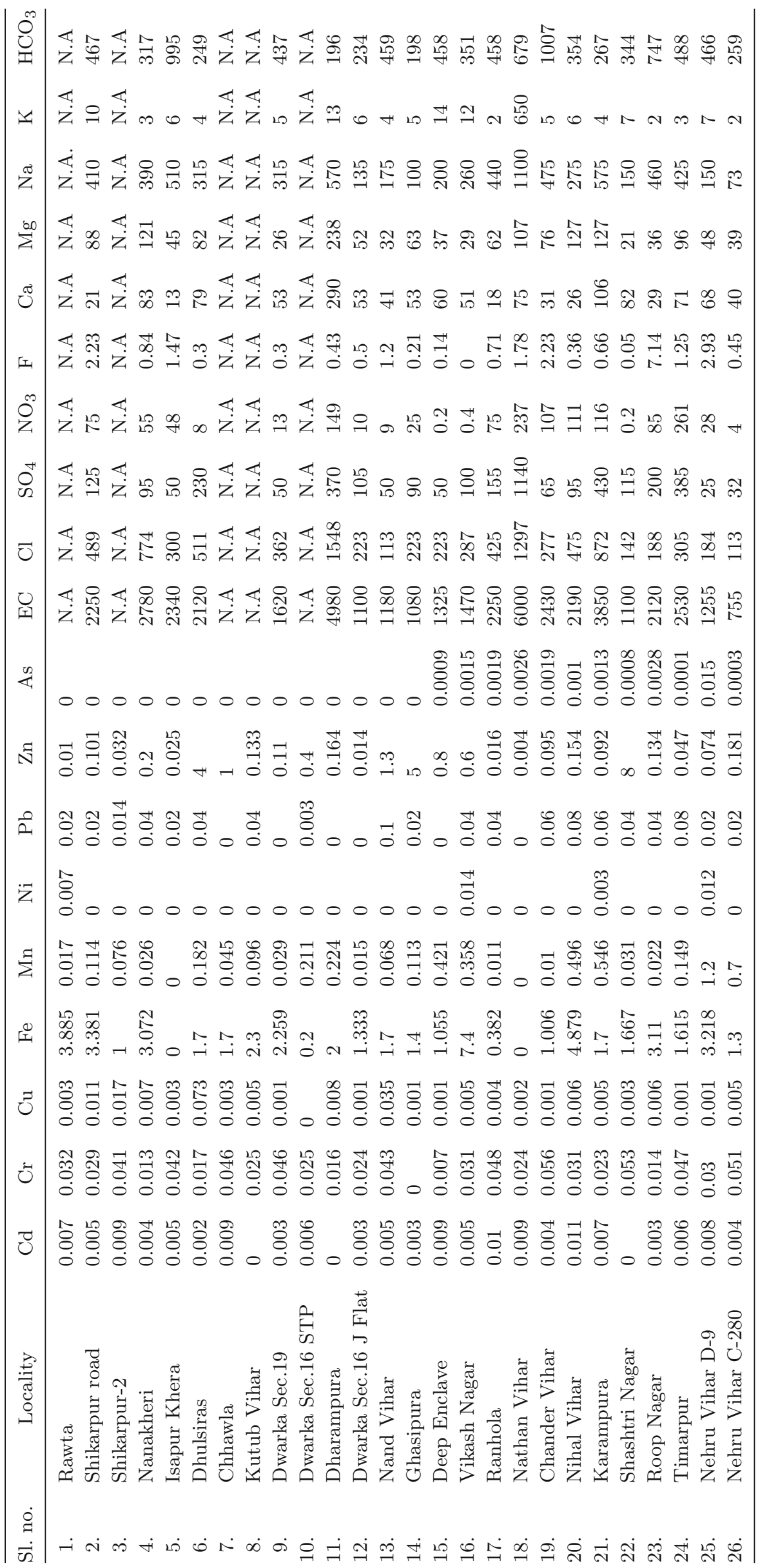




\section{References}

Bajpai 2011 Hydrogeological studies in the National Capital Territory of Delhi with reference to land use pattern and effective groundwater management; Proc. Indian Nat. Sci. Acad. 77(1) 31-49.

Banerjee A D K 2003 Heavy metal levels and solid phase speciation in street dust of Delhi, India; Environ. Pollut. 123 95-105.

BIS 1991 Indian Standard Specifications for drinking water; B.S.10500.

CGWB 2006 Hydrogeologic Framework of NCT Delhi; Report, Central Ground Water Board, Delhi, Ministry of Water Resources, Government of India.

Datta P S, Bhattacharya S K and Tyagi S K $1996{ }^{18}$ O studies on recharge of phreatic aquifers and groundwater flow paths of mixing in the Delhi area; J. Hydrol. 176 25-36.

Dubey C S, Mishra B K, Shukla D P, Singh R P, Tajbakhsh M and Sakhare P 2012 Anthropogenic arsenic menace in Delhi Yamuna Flood Plains; Environ. Earth Sci. 65 131-139.

Goel Y K 1990 Infiltration study in Pappan Kalan area, New Delhi, Report, Government of India, Central Ground Water Board, Ministry of Water Resources, Northwestern Region, Chandigarh.

INTACH 2003 Installation of tube wells and treatment of water along Najafgarh drain; Detailed Project Report (sponsored by Delhi Jal Board), Indian National Trust for Art and Cultural Heritage (INTACH), 71, Lodhi Estate, New Delhi 110003.

Jindal M C 1975 The groundwater conditions around Najafgarh Jhil in parts of Delhi and Haryana State; Report, Government of India, Central Ground Water Board, Ministry of Water Resources, North-western Region, Chandigarh.

Kumar M, Ramanathan A L, Rao M S and Kumar B 2006 Identification and evaluation of hydrochemical processes in the groundwater environment of Delhi, India; Environ. Geol. J. 50 1025-1039.

Kumar M, Ramanathan A L, Rao M S and Kumar B 2011 Identification of aquifer-recharge zones and sources in an urban development area (Delhi, India), by correlating isotopic tracers with hydrological features; Hydrogeol. J. 19 463-474.

Lalwani S, Dogra T D, Bhardwaj D N, Sharma R K, Murty O P and Vij A 2004 Study on Arsenic level in groundwater of Delhi using hydride generator accessory coupled with atomic absorption spectrometer; Ind. J. Clin. Biochem. 19(2) 135-140.

Lorenzen G, Sprenger C, Taute T, Pekdeger A, Mittal A and Massmann G 2011 Assessment of potential for bank filtration in water stressed megacity (Delhi, India); Environ. Earth Sci. 61 1419-1434.

Moturi M C Z, Rawat M and Subramanium V 2004 Distribution and fractionation of heavy metals in solid waste from selected sites in the industrial belt of Delhi, India; Environ. Monit. Assess. 95 183-199.

NEERI 2002 Environmental management plan for rejuvenation of river Yamuna; Report (sponsored by Delhi Development Authority), National Environmental Engineering Research Institute (NEERI), Nagpur 440020.
Rao S V N, Kumar S, Shekhar S and Chakraborti D 2006 Optimum pumping from skimming wells; J. Hydrol. Eng. $11464-471$.

Rao S V N, Kumar S, Shekhar S, Sinha S K and Manju S 2007 Optimum pumping from skimming wells from the Yamuna river flood plain in north India; Hydrogeol. J. 15 1157-1167.

Sarkar A 2011 The hydrochemical facies variation in groundwater along Najafgarh drain in National Capital Territory, Delhi vis-à-vis trace element concentration in groundwater; M.Sc. dissertation, Department of Geology, University of Delhi, Delhi 7.

Sharma B, Kumar M and Ramanathan A L 2004 Impact of surface water on the groundwater quality in and around Najafgarh drain, Delhi; In: Freshwater management (eds) Ramesh R and Ramachandran S (Delhi: Capital Publications Co.), pp. 70-86.

Shekhar S 2004 Integrated groundwater management study of south-west district with special reference to fresh/saline water interface; Report, Central Ground Water Board, Delhi, Ministry of Water Resources, Government of India.

Shekhar S 2006 An approximate projection of availability of the fresh groundwater resources in south-west district of NCT Delhi, India - A case study; Hydrogeol. J. 14 1330-1338.

Shekhar S 2008 Integrated groundwater management study in New Delhi, central, west, north-east, east and south districts, NCT Delhi with special reference to surface water-groundwater interaction along the Najafgarh drain; Report, Central Ground Water Board, Ministry of Water Resources, Delhi.

Shekhar S, Singh S B and Romani S 2005 The controls to the variation in depth to fresh/saline interface in the groundwater of south-west District, NCT Delhi - A case study; J. Geol. Soc. India 66 17-20.

Shekhar S, Mohiddin S K and Singh P N 2006 Variation in concentration of fluoride in the groundwater of south-west district, NCT Delhi - A case study; In: Assessment of groundwater resources and management (eds) Ramanathan A L, Bhattacharya P, Keshari A K, Bundschuh J, Chandrashekharan D and S K Singh (New Delhi: I K International), pp. 370-376.

Shekhar S, Purohit R and Kaushik Y B 2009 Groundwater management in NCT Delhi; Technical paper included in the special session on Groundwater in the 5th Asian Regional Conference of INCID, December 9-11, 2009 held at Vigyan Bhawan, New Delhi, available online at http://www.cgwb.gov.in/documents/papers/INCID.html.

Singh R B 1999 Impacts of urban growth on surface water and groundwater quality; Proc. IUGG 99 Symposium HS5, Birmingham, July 1999, IAHS 259 227-231.

WAPCOS 1999 Prefeasibility study for construction of a parallel channel to intercept the flows from Nallas out falling into river Yamuna between Wazirabad barrage and Okhla barrage, draft final prefeasibility report for Irrigation and Flood Control Department, Government of NCT Delhi, Report, Water and Power Consultancy Services (India) Limited, A Government of India Undertaking, 9, Community Centre, Saket, New Delhi 17.

WHO 2011 Guidelines for drinking water quality (4th edn), World Health Organization. 